\title{
Identification of Pathogenic Bacteria on Spiny Lobster (Panulirus homarus) at Quality Control and Fishery Product Safety Agency (BKIPM) of Bengkulu
}

\author{
Risky Hadi Wibowo ${ }^{1 *}$ Welly Darwis ${ }^{1}$ Sipriyadi ${ }^{1}$ Novi Susianti ${ }^{3}$ Kukuh Andias \\ Purbianto $^{3}$ Gustriana $^{3}$ Nadya Rosianti ${ }^{2}$ Della Indah Medani ${ }^{2}$ \\ Gustina Dwi Wulandari ${ }^{2}$ \\ ${ }^{1}$ Department of Biology, Faculty of Mathematics and Natural Sciences, Universitas Bengkulu, Kandang Limun, \\ Bengkulu 38112, Indonesia. \\ ${ }^{2}$ Undergraduate Student, Department of Biology, Faculty of Mathematics and Natural Sciences, Universitas \\ Bengkulu, Kandang Limun, Bengkulu 38112, Indonesia \\ ${ }^{3}$ Quality Control and Fishery Product Safety Agency (BKIPM) of Bengkulu, Bengkulu, 38213, Indonesia. \\ Corresponding author: Email: riskyhadiwibowo80@gmail.com
}

\begin{abstract}
Lobster (Panulirus homarus) or spiny lobster is one of the export commodities of the Indonesian fisheries subsector and an important component for shrimp fisheries in Indonesia. This commodity needs to be further developed because of its high trade value and potential. Lobster enlargement cultivation in Indonesia began in early 2000, with the discovery of puerulus attachments in the waters of the bay of Lombok. However, in this lobster cultivation business failure often occurs due to the high mortality caused by infectious diseases which are generally caused by bacterial, parasitic, fungal, and viral infections. The bacteria that infect lobsters can reduce the expected production target. However, bacteria in lobster culture could have beneficial or harmful effects, depending on the prevailing conditions. This study aims to identify bacteria in spiny lobsters (Panulirus homarus). Bacterial isolation came from organs in spiny lobsters, that are hepatopancreas and hemolymph. Bacteria isolates were identified through their colony morphology and biochemical tests. Characterization on the Thiosulfate Citrate Bile Salt Sucrose medium showed that lobsters were infected with Vibrio. Based on Bergey's Manual of Determinative Bacteriology and Nial, the results showed that the Hepatopancreas in first lobsters were infected with Vibrio algynolyticus that mostly in the Hepatopancreas. The second sample was found to be infected with Vibrio damsela that mostly in the Hepatopancreas. However, no bacteria were found in spiny lobster hemolymph.
\end{abstract}

Keywords: Panulirus homarus, Vibrio algynolyticus, Vibrio damsela

\section{INTRODUCTION}

Lobsters are large crustaceans scattered in tropical and subtropical waters. Panulirus lobsters belong to the Palinuridae family and commonly referred to as spiny lobsters [1]. One of the lobsters of the genus Panulirus spread across Indonesia is Panulirus homarus. Lobster (Panulirus homarus) or spiny lobster is one of the export commodities of the Indonesian fisheries subsector and an important component for shrimp fisheries in Indonesia. This commodity needs to be further developed because of its high trade value and potential. Lobster cultivation in Indonesia began in early 2000, with the discovery of puerulus attachments in the waters of the bay of Lombok. The potential for developing this cultivation is supported by the transfer of knowledge and technology from the lobster cultivator community in Vietnam. Among several lobster species, Panulirus homarus has the advantage of being selected as a 
candidate for cultivated species. This is related to market demand, high prices, and availability of seeds in nature [2]. However, in this lobster cultivation business failure often occurs due to the high mortality caused by disease infections [3], which is generally caused by bacterial, rickettsia-like bacteria, parasites, fungi, and viruses [4]. This study aims to identify bacteria in spiny lobsters (Panulirus homarus).

\section{MATERIALS AND METHODS}

\subsection{Research Material}

The tools and materials used in this study were Petri dishes, Erlenmeyer, test tubes, test tubes racks, inoculation loop, glass objects, incubator, refrigerator, analytical scales, oven, trays, spatulas, measuring cylinder, spray bottles, surgical instruments, beakers glass, bunsen burner, micropipette, tube, UV-Laminar flow, magnetic stirrer, hotplate, autoclave, stationery, cotton, tissue, label paper, wrapping paper, matches, rubber bands, aluminum foil, and bacteria identification forms, spiny lobsters (Panulirus homarus), 70\% alcohol, spritus, absolute alcohol, iodine, paraffin, oxidase paper, $\mathrm{KOH}(40 \%), \mathrm{KOH}$ solution (3\%), $\mathrm{H} 2 \mathrm{O} 2$ solution (3\%), aquadest, Methyl Red solution, Kovack's solution, $\alpha$-naphthol solution, Simmons Citrate Agar media, Trypticase Soy Agar, Triple Sugar Iron Agar, Lysine Iron Agar media, Motility Indole Ornithine media, MR-VP media, OxidativeFermentative media, Urease media, Phenol-Red Broth Base, Glucose, Maltose, Lactose, Mannitol, Sorbitol, Gelatin, Thiosulfate Citrate Bile Salts Sucrose (TCBS) media.

\subsection{Spiny Lobsters (Panulirus homarus) Sample Collection}

Samples were obtained from spiny lobsters (Panulirus homarus). Furthermore, in living conditions, samples were analyzed at the Testing Laboratory, Fish Quarantine Station, Quality Control, and Safety of Fishery Products (SKIPM) Bengkulu.

\subsection{Isolation of Target Pathogenic Bacteria from Spiny Lobsters (Panulirus homarus) Sample}

The body surface of the spiny lobster cleaned with iodine using a tissue. Bacteria isolated from the target organs, namely hepatopancreas and hemolymph using an inoculation loop that had been glazed over the bunsen onto the Trypticase Soy Agar media with streak method and incubated for $1 \times 24$ hours at room temperature. Isolates grown on the media were inoculated and purified.

\subsection{Identification of Bacterial Colony Characteristics by Biochemical Test}

Identification of bacterial colonies using biochemical tests, namely Potassium hydroxide Test, catalase test, oxidase test, gelatin test, Lysine Iron Agar test, Oxidative-Fermentative test, Motility Indole Ornithine test, Simmons citrate test, Triple Sugar Iron Agar test, MR-VP test, Urease test, Thiosulfate Citrate Bile Salts Sucrose (TCBS) test, Carbohydrate tests including glucose, maltose, lactose, sorbitol, and mannitol.

\subsection{Identification of Bacterial Isolates from Target Organs, Hepatopancreas and Hemolymph of Spiny Lobsters (Panulirus homarus)}

Identification of the type of bacteria carried out by adjusting the test results and characteristics of the bacteria that were available on the identification sheet using Bacterial identification book from Bergey's Manual of Determinative Bacteriology 9th Edition [5], Bergey's Manual of Systematic Bacteriology 2nd Edition Volume 3rd [6].

\section{RESULT AND DISCUSSION}

\subsection{External morphology of Spiny Lobster (Panulirus homarus)}

The external morphology of spiny lobsters consists of a cephalothorax protected by a strong and spiny carapace, and a carapace-covered abdomen, and a tail. Spiny lobsters have 9 pairs of batteries consisting of 5 pairs of walking legs and 4 pairs of swimming legs (Pleupod). The carapace of the sand lobsters is bluish-gray and there are bright yellow spots. The sample used in this study was male spiny lobster. It can be seen from the swimming feet where there is only 1 sheet of swimming feet (Figure 1).

According to [7] that the swimming foot is only one sheet, the second sheet does not grow at all, only in the form of a blunt-like protrusion. Observation of bacterial colony morphology in Spiny Lobsters (Panulirus homarus) can be seen in (Table 1) and (Figure 2 and Figure 3). 

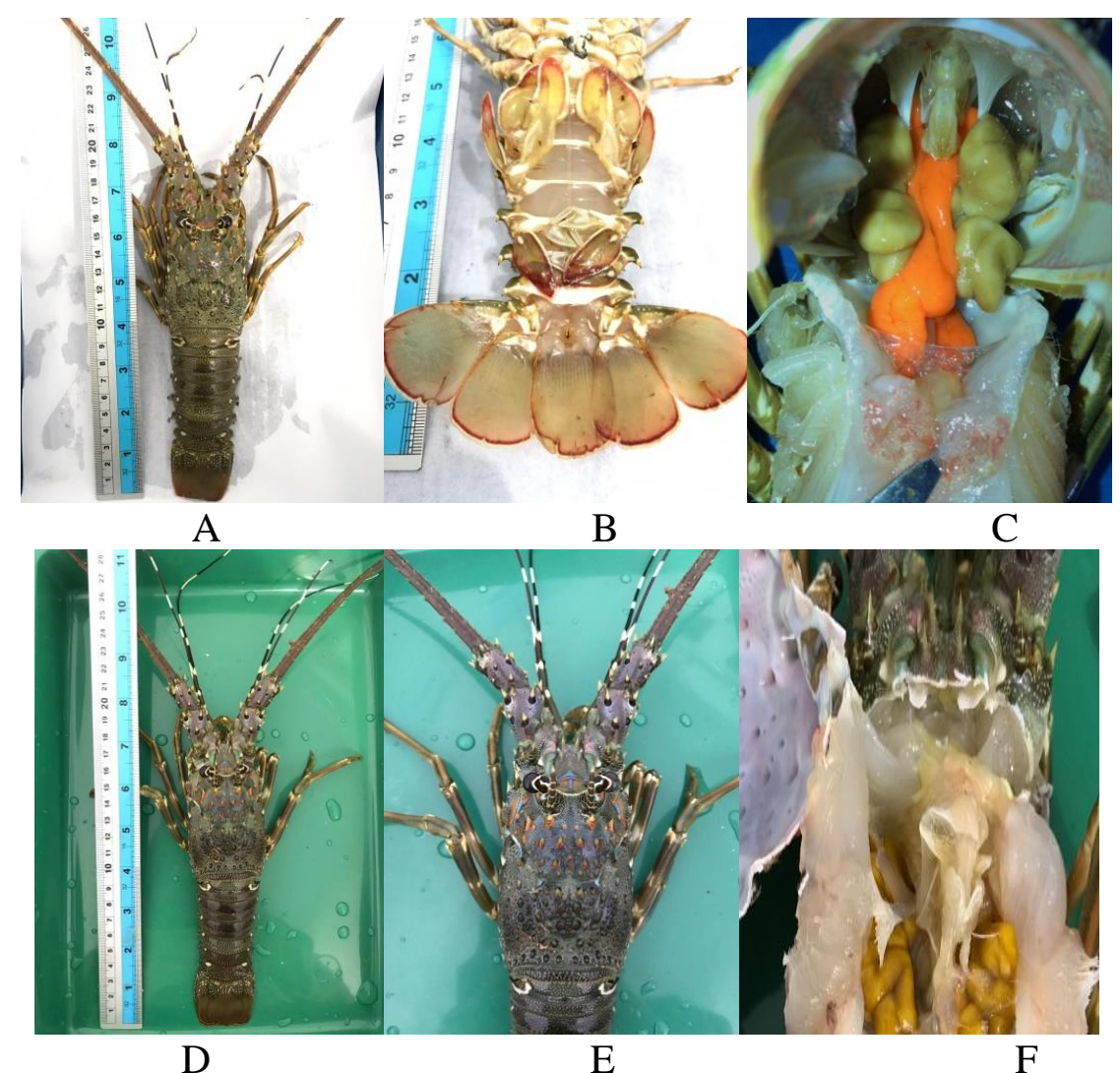

Figure 1. External morphology of Spiny Lobster (Panulirus homarus) on the (A) full body 1, (B) abdomen (Telson) 1 (C) Hepatopancreas 1; (D) Full body 2, (E) Carapacs, (F) Hepatopancreas 2.

Table 1. Identification of Bacterial Colony Morphology

\begin{tabular}{cccc}
\hline \multirow{2}{*}{$\begin{array}{c}\text { Bacterial } \\
\text { Morphology }\end{array}$} & \multicolumn{3}{c}{ Isolated Organs } \\
\cline { 2 - 4 } Color & Hepatopancreas 1 & Hepatopancreas 2 & Hemolymph \\
\hline Margin & Entire & Cream & - \\
Elevation & Convex & Entire & - \\
Form & Circular & Convex & - \\
\hline
\end{tabular}

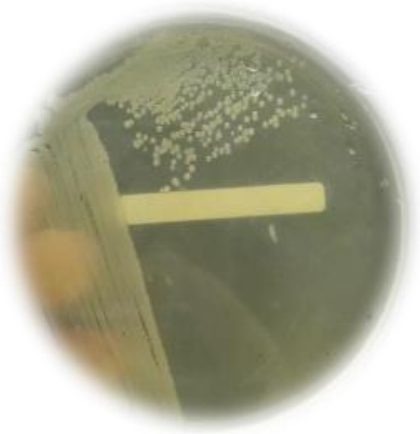

A

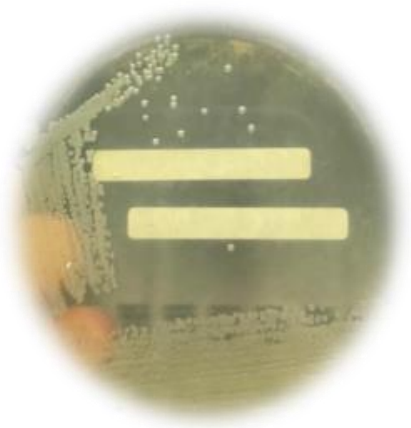

B

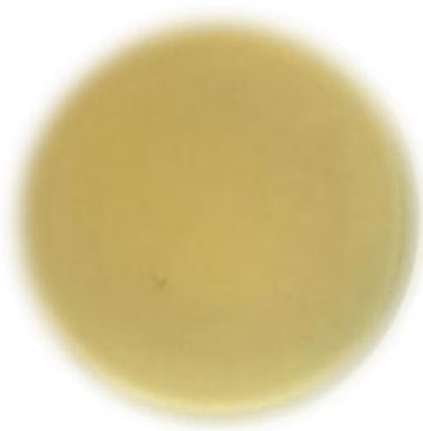

$\mathrm{C}$

Figure 2. Bacterial isolates from Spiny Lobster organs on Trypticase Soy Agar (TSA) media and incubated at $25^{\circ} \mathrm{C}$ for $1 \times 24$ hours (A) Hepatopancreas 1, (B) Hepatopancreas 2 (C) Hemolymph in Spiny Lobster (Panulirus homarus). 


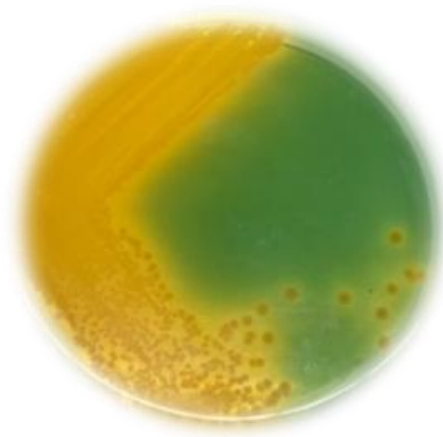

A

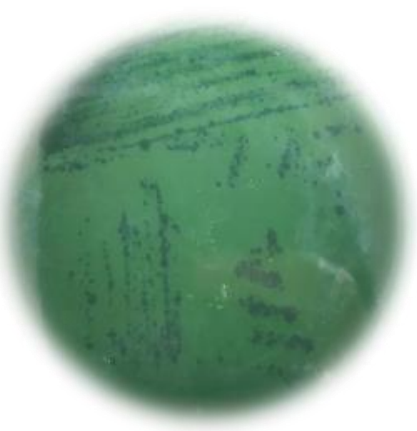

B

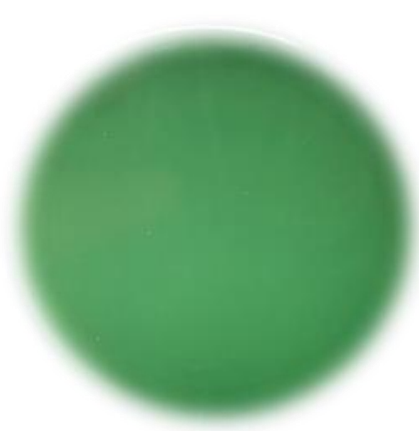

C

Figure 3. Bacterial isolates from spiny lobster organs on the Thiosulfate citrate bile salts sucrose (TCBS) agar and incubated at $25^{\circ} \mathrm{C}$ for $1 \times 24$ hours (A) Hepatopancreas 1, (B) Hepatopancreas 2 (C) Hemolymph in Spiny Lobster (Panulirus homarus).

Table 2. Identification of bacteria by biochemical test

\begin{tabular}{lcccc}
\hline & \multicolumn{3}{c}{ Isolated Organs } & \\
\cline { 2 - 4 } Biochemical Tests & $\mathbf{1}$ & $\mathbf{2}$ & Hemolymph & Note \\
\cline { 2 - 5 } & Hepatopancreas & Hepatopancreas & Gotassium \\
hydroxide Test & Gram-negative & Gram-negative & Gram-negative & $\begin{array}{c}\text { Solution be viscous and form a } \\
\text { mucoid string }\end{array}$ \\
Catalase Test & + & + & + & Bubbles of oxygen \\
Oxidase Test & + & + & + & purple color \\
\hline
\end{tabular}

Table 3. Identification of bacteria by biochemical test

\begin{tabular}{|c|c|c|c|c|c|c|}
\hline \multirow{2}{*}{\multicolumn{2}{|c|}{ Biochemical Test }} & \multicolumn{3}{|c|}{ Isolated Organs } & \multicolumn{2}{|c|}{ Positive Control } \\
\hline & & $\begin{array}{c}\text { Hepatopancreas } \\
1\end{array}$ & $\begin{array}{c}\text { Hepatopancreas } \\
2 \\
\end{array}$ & Hemolymph & $\begin{array}{c}\text { Vibrio } \\
\text { alginolyticus }\end{array}$ & $\begin{array}{c}\text { Vibrio } \\
\text { Damsela }\end{array}$ \\
\hline & Motility & + & + & - & $+^{*}$ & $+^{*}$ \\
\hline \multirow[t]{2}{*}{ MIO Test } & Indole & + & - & - & $+* *$ & $-*$ \\
\hline & Ornithine & + & - & - & $+* * *$ & $-*$ \\
\hline \multicolumn{2}{|c|}{ Gelatin Hydrolysis Test } & + & - & - & $+^{*}$ & $-*$ \\
\hline & MR & + & + & - & $+^{*}$ & $+*$ \\
\hline \multicolumn{7}{|l|}{ MR-VP Test } \\
\hline & VP & + & + & - & $+*$ & $+*$ \\
\hline & Glucose & + & + & - & $+^{*}$ & $+^{*}$ \\
\hline & Lactose & - & - & - & $-* *$ & No data \\
\hline \multirow[t]{3}{*}{$\begin{array}{c}\text { Carbohydrate } \\
\text { Tests }\end{array}$} & Maltose & + & + & - & No data & No data \\
\hline & Mannitol & + & + & - & $+^{*}$ & $+^{*}$ \\
\hline & Sorbitol & - & - & - & $-*$ & $-*$ \\
\hline
\end{tabular}




\begin{tabular}{|c|c|c|c|c|c|c|}
\hline \multicolumn{2}{|c|}{ Oxidative-Fermentative Test } & $\mathrm{F}$ & $\mathrm{F}$ & - & $\mathrm{F}^{*}$ & $\mathrm{~F}^{*}$ \\
\hline & Slunt/Butt & $\mathrm{A} / \mathrm{A}$ & $\mathrm{K} / \mathrm{A}$ & - & No data & No data \\
\hline \multirow[t]{2}{*}{$\begin{array}{l}\text { Triple } \\
\text { Iron Agar ' }\end{array}$} & $\begin{array}{l}\text { Sugar } \\
\text { Test }\end{array}$ & - & - & - & $-*$ & $-*$ \\
\hline & Gas & - & + & - & No data & No data \\
\hline \multicolumn{2}{|c|}{ Simmons Citrate Agar Test } & + & - & - & No data & No data \\
\hline \multirow{2}{*}{$\begin{array}{l}\text { Lysine } \\
\text { Iron Agar } \\
\text { Test }\end{array}$} & $\begin{array}{c}\text { Lysine } \\
\text { Decarboxylase }\end{array}$ & + & - & - & $+* *$ & $-*$ \\
\hline & $\begin{array}{c}\text { Lysine } \\
\text { Deaminase }\end{array}$ & - & + & - & $-* *$ & No data \\
\hline \multicolumn{2}{|c|}{ Urease Test } & - & + & - & $-*$ & $+^{*}$ \\
\hline \multicolumn{2}{|c|}{$\begin{array}{l}\text { Thiosulfate citrate bile salts } \\
\text { sucrose }(T C B S) \text { Agar }\end{array}$} & Yellow & Green & - & Yellow $* * * *$ & Green* \\
\hline
\end{tabular}

Control sources:

* Bacterial identification book from the testing laboratory, Fish Quarantine Station, Bengkulu Fishery Product Quality and SafetyControl.

$* *$ Identification results from the research of [5]

$* * *$ Identification results from the research of [8]

**** Identification results from the research of [9].

Based on the biochemical assay in the table 2 and table 3 , the data showed various results such as in the gelatin test, bacterial isolates from hepatopancreas 1 showed positive results, while bacterial isolates from hepatopancreas 2 showed negative results. According to [10] that bacteria have the gelatinase enzyme with gelatin unable to form and will become liquid.

In the motility test, two sample isolates have positive results, the bacteria were motile. In the Indol test, hepatopancreas 1 showed positive results, which means that the isolate bacteria were able to produce indole from the amino acid tryptophan through the tryptophanase enzyme. However, Hepatopancreas 2 showed negative result which were not able to produce indole from the amino acid tryptophan

In the Methyl-Red (MR) test showed two bacterial isolates showed positive result. Voges Proskauer (VP) test on bacterial isolates from two samples showed positive results. According to [13] that the MR test is to see the ability of bacteria to oxidize glucose by producing acid at high concentrations, and the VP test to detect acetoin in bacterial cultures. A positive result will indicate a change in color to red, while a yellow-brown color indicates a negative result.

In the Triple Sugar Iron Agar test, the hepatopancreas 1 isolates showed yellow on the slant (oblique part) and yellow on the butt (stem part) that showed the bacteria are acidic (acidic). through the tryptophanase enzyme. Ornithine test results, bacterial isolates from hepatopancreas 1 showed positive test results, while bacterial isolates from hepatopancreas 2 showed negative test results. According to [11] that the tryptophanase enzyme and have the ornithine decarboxylase enzyme.

In the oxidative-fermentative test, two isolates showed the color of media change from blue to yellow, both in the tube with paraffin or not. According to [12] that the principle of the oxidative/fermentative test of the media covered with paraffin changes color from blue to yellow, so bacteria can utilize carbohydrates in anaerobic conditions and are said to be fermentative.

Hepatopancreas 2 showed red on the slant (oblique part) yellow on the butt (stem part), and the bacteria are saline (alkaline), and yellow on the butt (stem part) that showed the bacteria are acidic (acidic). Two isolates did not produce $\mathrm{H} 2 \mathrm{~S}$. Bacterial isolates from Hepatopancreas 2 showed gas, and bacterial isolates from hepatopancreas 1 had no gas. According to [14] that reading the test results usually starts from the slope of the media. If the test results show A / K (red slope, yellow base), this means that the bacteria can only partially ferment carbohydrates. The A / A test results mean that bacteria can ferment all types of carbohydrates, while the $\mathrm{K} / \mathrm{K}$ that the tested bacteria cannot ferment all types of carbohydrates. 
According to [12] that Triple Sugar Iron Agar media is used to determine the ability of bacteria to use glucose, lactose, sucrose, and the ability of bacteria to produce gas or hydrogen sulfide $\left(\mathrm{H}_{2} \mathrm{~S}\right)$.

In the carbohydrate tests, two bacterial isolates showed positive results in the glucose, maltose, and mannitol tests and negative results in lactose and sorbitol. In the urease test, bacterial isolates from hepatopancreas 1 showed positive results, while bacterial isolates from hepatopancreas 2 showed negative results. According to [14] that urease test aims to determine the ability of bacteria to convert urea into ammonia.

In the Lysine Iron Agar Test, hepatopancreas 1 and hepatopancreas 2 showed the positive results of lysine decarboxylase. hepatopancreas 1 and hepatopancreas 2 showed negative result of lysine deaminase. According to [15] that lysine decarboxylase test that showed positive results were purple (purple) isolates on all parts both on the bottom of the media and the slanted part of the media and able to deaminase lysine showed a faded or yellow color change.

In the Simmons citrate test, bacterial isolates from hepatopancreas 1 showed positive results, while the bacterial isolates from hepatopancreas 2 showed negative results. According to [16] that Simmons citrate media contains the BTB indicator (Brom Thymol Blue), bacteria use citrate as a carbon source.

In the carbohydrate tests, two bacterial isolates showed positive results in the glucose, maltose, and mannitol tests and negative results in lactose and sorbitol. According to [5] that Vibrio alginolyticus can ferment glucose and mannitol.

In the thiosulfate citrate bile salts sucrose (TCBS) media, Bacterial isolates from hepatopancreas 1 showed yellow colony color and Bacterial isolates from hepatopancreas 2 showed green colony color. Thiosulfate citrate bile salts sucrose agar was one of the first selective media used for the isolation and purification of vibrios [17], and is still largely employed. TCBS has been widely employed for the isolation of pathogenic vibrios from clinical specimens and food, as well as from the aquatic environment. Moreover, it is also indicated as isolation/enumeration medium for all vibrios, a bacterial group abundant mainly in estuarine and sea waters, as well as seafood [18]. On this medium, different Vibrio species (i.e., $V$. cholerae, $V$. alginolyticus, $V$. harveyi) can be differentiated based on the ability of fermenting sucrose, which results in yellow colonies [19]. In contrast, sucrose nonfermenters, such as $V$. damsela appear in green colonies. Based on colony morphology observation and biochemical test, bacterial isolate from hepatopancreas 1 have close relationship with Vibrio alginolyticus and bacteria isolate from hepatopancreas 2 have close relationship with Vibrio damsela. According to [20] that Vibrio species classified as pathogenic included: $V$. alginolyticus and $V$. damsela (Listonella damsela).

\section{CONCLUSION}

Based on biochemical tests carried out such as oxidase test, catalase test, Simmons Citrate test, Triple Sugar Iron Agar, Oxidative-Fermentative, Motility Indol Ornithine, Lysine Iron Agar, MR-VP, urease, gelatin, and Thiosulfate citrate bile salts sucrose (TCBS) test, Bacterial isolate from hepatopancreas 1 have close relationship with Vibrio alginolyticus and Bacteria isolate from hepatopancreas 2 have close relationship with Vibrio damsela.

\section{ACKNOWLEDGMENT}

The author would like to thank Quality Control and Fishery Product Safety Agency (BKIPM) of Bengkulu, Biology Department, Faculty of Mathematics and Natural Sciences, as well as to all parties who have helped the completion of this research.

\section{REFERENCES}

[1] L.B. Holthuis, Marine lobster of the world, FAO Fisheries Synopsis 13 (125) (1991) 139141.

[2] Food and Agriculture Organization of the United Nations (FAO), Cultured aquatic species information program: Panulirus homarus,

(2015),http://www.fao.org/fishery/culturedspe cies/ Panulirus_homarus/en. [Retrieved on 03 July 2015].

[3] J.D. Shields, Diseases of spiny lobsters: a review, Journal of Invertebrate Pathology 106 (1) ((2011) 79-91.

[4] V.V. Nha, D.T. Hoa, L.V. Khoa, Black gill disease of cagecultured ornate rock lobster Panulirus ornatus in central Vietnam caused by Fusarium species, Aquaculture Asia Magazine 11 (4) (2009) 35-37.

[5] J.G. Holt, N.R. Krieg, P.H.A. Sneath, J.T. Staley S.T. Williams, Bergey's manual of 
determinative bacteriology, 9th ed, William and Wilkins. USA: Departement of Microbiology, Gltner Hall, Michigan State University, East lansing, 1994.

[6] W. Whitman, M. Goodfellow, P.Kampfer, H. J. Busse, M. Trujilo, W. Ludwig, K. Suzuki, A. Parte, Bergey's Manual of Systematic Bacteriology 2nd Edition Volume $3^{\text {rd }}$, New York: Springer, 2009.

[7] Sukanto, T. Muryanto, H. Kusiani, Teknik Identifikasi Jenis KelaminLobster Berbasis Ciri-ciri Morfologi, Buletin Teknik Litkayasa 15 (2) (2017) 99-102.

[8] E.L. Elliot, A.C. Kaysner, M.L. Tamplin, V. cholerae, V. parahaemolyticus, V. vulnificus and other Vibrio spp, In Bacteriological Analytical Manual Online, Chapter 9, 9th edn, US: FDA Centre for Food Safety and Applied Nutrition 2001.

[9] D.V. Lightner, A handbook of shrimp pathology and diagnostic procedures for diseases of culture penaeid shrimp, Sec. 4: Bacteria, vibriosis-culture and identification, The World Aquaculture Society, Baton Rouge, Lousiana, 1996.

[10] M. Arwin, F.G. Ijong, R. Tumbol, Characteristics of Aeromonas hydrophila isolated from tilapia (Oreochromis niloticus). Aquatic Science and Management 4(2) (2016) 58.

[11] W. Tantu, A.T, Reiny, N.J. Sammy, Detection of the presence of Aeromonas sp. bacteria in tilapia cultivated in floating net cages, Tondano Lake, Jurnal Budidaya Perairan 1 (3) (2013) 74-80.

[12] R. Purnamawati, Fish disease inspection methods at fish quarantine center for quality and safety control of class I fishery products Surabaya I, Undergraduate Thesis, University of Airlangga: Undergraduate Program of Aquaculture, 2016.

[13] V. Hemraj, E review on commonly used biochemical Test for Bacteria, Innofare journal of life science 1 (1) (2013) 1-7.

[14] Ulfa, S. Endang, H. Mimien, Isolation and Sensitivity Test of Mercury on Bacteria from Gold Mining Waste in Sekotong Barat, West Lombok Regency: Preliminary Research. Proceeding Biology Education Conference, 2016.

[15] Rondonuwu, Description of $\mathrm{HgCl}_{2}$ and Phenyl Mercury Resistance Bacteria Taken from Feces, Urine, and Tartar in Individuals, Jurnal e-Biomedik (eBM) 2(3) (2014).

[16] T.J. Chandra, S. Mani, A study of 2 rapid tests to differentiate Gram positive and Gramnegative aerobic bacteria, Journal of Medical and Allied Sciences 1 (2) (2011) 84-85.

[17] J.D. Oliver, Vibrio vulnificus In Belkin S., \& Colwell R. R. (Eds.), Oceans and health: pathogens in the marine environment, Springer Science, New York, 2006.

[18] T.L. Madigan, N.J. Bott, V.A. Torok, N.J. Percy, J.F. Carragher, M.A. de Barros Lopes, A. Kiermeier, A microbial spoilage profile of half shell Pacific oysters (Crassostrea gigas) and Sydney rock oysters (Saccostrea glomerata), Food Microbiology, 38 (2014) 219-227.

[19] F.L. Thompson, T. Iida, J. Swings, Biodiversity of vibrios, microbiology and molecular biology reviews, 68 (2004) 403431

[20] B. Austin, Vibrios as causal agents of zoonoses, Veterinary Microbiology, 140 (2010)1-34. 